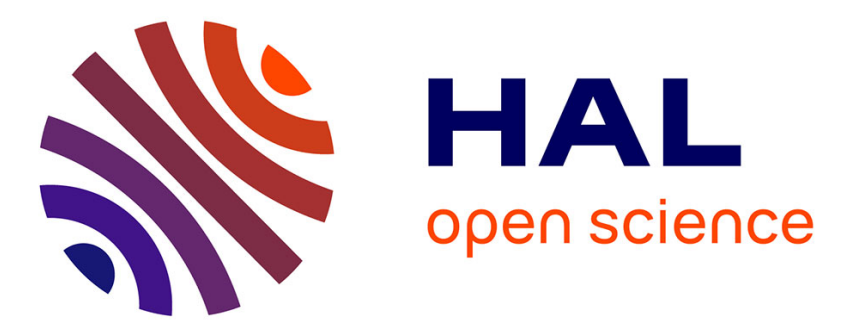

\title{
Simulation of the gastric digestion of proteins of meat bolus using a reaction-diffusion model
}

Jason Sicard, Pierre-Sylvain Mirade, Stéphane Portanguen, Sylvie Clerjon, Alain Kondjoyan

\section{- To cite this version:}

Jason Sicard, Pierre-Sylvain Mirade, Stéphane Portanguen, Sylvie Clerjon, Alain Kondjoyan. Simulation of the gastric digestion of proteins of meat bolus using a reaction-diffusion model. Food and Function, 2018, 9 (12), pp.6455-6469. 10.1039/C8FO01120F . hal-01985356

\section{HAL Id: hal-01985356 https://hal.science/hal-01985356}

Submitted on 26 May 2020

HAL is a multi-disciplinary open access archive for the deposit and dissemination of scientific research documents, whether they are published or not. The documents may come from teaching and research institutions in France or abroad, or from public or private research centers.
L'archive ouverte pluridisciplinaire HAL, est destinée au dépôt et à la diffusion de documents scientifiques de niveau recherche, publiés ou non, émanant des établissements d'enseignement et de recherche français ou étrangers, des laboratoires publics ou privés.

\section{(ㄷ)(1) $\$$}

Distributed under a Creative Commons Attribution - NonCommerciall 4.0 International 


\section{ABSTRACT:}

A reaction-diffusion mathematical model has been developed to predict the gastric digestion of meat proteins. The model takes into account pepsin diffusion and proton diffusion in bolus particles and the $\mathrm{pH}$ buffering capacity of the meat. The computations show that size of bolus particles and change in gastric $\mathrm{pH}$ have a substantial effect on the percentage of protein digested in the stomach and that the $\mathrm{pH}$ buffering capacity of the meat has to be accounted for to properly calculate the gastric digestibility of meat. The intensity of surface transfers between stomach fluid and bolus particle has a significant impact on protein digestibility, whereas the variations in pepsin content in the stomach between individuals appears to have little effect on protein digestibility. From a nutritional standpoint, the simulations show that meat protein digestibility is high in normal physiological stomach conditions. However, in a situation where masticatory capacity, hydrochloric acid secretion and gastric motor function performances are reduced, such as with advancing age, protein digestibility rapidly decreases, ultimately leading to near-zero digestibility value in the stomach in extreme cases.

HIGHLIGHTS:

- Mathematical model predicts the gastric digestion of meat

- Quantification of the effects of physiological factors on meat digestion

- Protein digestibility is driven mainly by gastric $\mathrm{pH}$ and bolus particle size

KEYWORDS: transfer, kinetics, model, stomach, beef meat, pepsin, digestibility 


\section{List of symbols used:}

D: mass diffusivity of pepsin or proton in water $\left(\mathrm{m}^{2} . \mathrm{s}^{-1}\right)$

E: enzyme concentration (U. $\mathrm{mg}^{-1}$ )

$\mathrm{E}^{\mathrm{pH}}$ : active enzyme concentration, which is $\mathrm{pH}$-dependent $\left(\mathrm{U} \cdot \mathrm{mg}^{-1}\right)$

$\mathrm{E}_{\max }^{* \mathrm{pH}}$ : fraction of active enzyme able to reach all the cleavage sites available on the protein (linked to $\mathrm{pH}$ and to maximum number of cleavage sites available)

$\mathrm{E}_{\max }^{* \mathrm{pH}=2}$ : maximum value of $\mathrm{E}_{\max }^{* \mathrm{pH}}$ for raw beef meat as measured on extracted myofibrils immersed for a very long time in a solution of pepsin at $\mathrm{pH} 2$ (optimum $\mathrm{pH}$ for pepsin activity); used as a reference value to calculate the digestibility ratios $\sigma, \overline{\sigma(t)}, \overline{\bar{\sigma}}$

$\mathrm{H}^{+}$: molar concentration of hydrogen ions $\left(\mathrm{mol}^{-\mathrm{l}^{-1}}\right)$

$\mathrm{k}_{\mathrm{HCl}}$ : mass transfer coefficient of hydrochloric acid at the gastric fluid-bolus particle interface $\left(\mathrm{m} . \mathrm{s}^{-1}\right)$

$\mathrm{k}_{\text {Pepsin }}$ : mass transfer coefficient of pepsin at the gastric fluid-bolus particle interface $\left(\mathrm{m} . \mathrm{s}^{-1}\right)$

$\mathrm{K}_{\mathrm{a} 1}$ : First pepsin dissociation constant (bi-acid behavior)

$\mathrm{K}_{\mathrm{a} 2}$ : Second pepsin dissociation constant (bi-acid behavior)

$\mathrm{K}_{\mathrm{H}}$ : coefficient of meat $\mathrm{pH}$ buffering capacity

$L$ : pseudo reaction rate constant, which depends on $I_{f}$ and on kinetic rate constants of the absorption and desorption reactions of the cleavage sites

$\mathrm{L}_{\text {car }}$ : characteristic length, in our model equal the diameter of a meat bolus particle, Size $(\mathrm{m})$

$\mathrm{I}_{\mathrm{f}}$ : kinetic rate constant of the formation of peptides and amino acids from protein cleavage $\left(\mathrm{min}^{-1}\right)$

P: relative concentration of the peptides and amino acids formed from protein cleavage $\mathrm{pH}$ : potential of hydrogen ( $\mathrm{pH}$ unit)

$\mathrm{pK}_{\mathrm{a} 1}$ and $\mathrm{pK} \mathrm{K}_{\mathrm{a} 2}$, equal to $-\log _{10}\left(\mathrm{~K}_{\mathrm{a} 1}\right)$ and $-\log _{10}\left(\mathrm{~K}_{\mathrm{a} 2}\right)$, respectively

$\mathrm{r}$ : radius of a meat bolus particle $(\mathrm{mm})$

Re: Reynolds number for bolus particles immersed in the gastric fluid $\left(=\left(\rho * \nu * L_{c a r}\right) / \mu\right)$

Sc: Schmidt number for the bolus particles immersed in the gastric fluid $(=\mu /(\rho * D))$ 
Sh: Sherwood number for the bolus particles immersed in the gastric fluid $\left(=k /\left(D / L_{\text {car }}\right)\right)$

Size: diameter of a meat bolus particle $(\mathrm{mm})$

t: time (s)

$t_{\text {end }}$ : time period from ingestion to the end of gastric emptying (s)

$t_{\text {lag: }}$ : time period from ingestion to the end of the lag phase of gastric emptying (s)

$t_{\bar{\sigma}=50 \%}$ : digestion time necessary to reach $50 \%$ digestibility of the proteins contained in the bolus particles relative to the maximum digestibility of extracted myofibrillar proteins $\left(E_{\max }^{* \mathrm{pH}=2}\right)(\mathrm{s})$

$\mathrm{t}_{\bar{\sigma}=75 \%}$ : digestion time necessary to reach $75 \%$ digestibility of the proteins contained in the bolus particles relative to the maximum digestibility of extracted myofibrillar proteins $\left(\mathrm{E}_{\max }^{* \mathrm{pH}=2}\right)(\mathrm{s})$

V: meat particle volume $\left(\mathrm{m}^{3}\right)$

$\delta_{\max }:$ product of $\mathrm{E}_{\max }^{* \mathrm{pH}}$ and of the calibration constant of the spectrophotometer

$\Delta$ : Laplace operator; in spherical coordinates without angular variations, may be simplified to $\Delta=$ $\frac{\partial^{2}}{\partial \mathrm{r}^{2}}+\frac{2}{\mathrm{r}} \frac{\partial}{\partial \mathrm{r}}$

$\mu$ : dynamic viscosity of the gastric fluid (Pa.s)

v: velocity of the gastric fluid around meat bolus particles $\left(\mathrm{mm} . \mathrm{s}^{-1}\right)$

$\rho:$ density of the gastric fluid $\left(\mathrm{kg} \cdot \mathrm{m}^{-3}\right)$

$\sigma:$ local digestibility ratio inside a meat particle relative to the maximum protein digestibility measured on extracted myofibrils immersed in a pepsin solution at $\mathrm{pH} 2\left(\%\right.$ of $\left.\mathrm{E}_{\max }^{* \mathrm{pH}=2}\right)$

$\overline{\sigma(t)}$ : digestibility of a meat particle, at a given time $t$ of digestion, ratioed to the maximum protein digestibility measured on extracted myofibrils immersed in a pepsin solution at $\mathrm{pH} 2\left(\%\right.$ of $\left.\mathrm{E}_{\max }^{* \mathrm{pH}=2}\right)$ $\overline{\bar{\sigma}}$ : mean digestibility ratio for a given bolus particle size after a given gastric residence time(\% of $\mathrm{E}_{\max }^{* \mathrm{pH}=2}$ )

Ф: mass transfer of pepsin or of protons at the meat particles-gastric fluid interface $\left(\mathrm{mol} \cdot \mathrm{m}^{-2} \cdot \mathrm{s}^{-1}\right)$

\section{Superscripts:}

+: gastric conditions most favorable to digestibility

-: gastric conditions least favorable to digestibility 
o: most probable average gastric conditions

\section{Subscripts:}

Free: ions which are not bonded to proteins, and are able to diffuse

Gastric: relative to the value in the gastric fluid, outside meat

$\mathrm{HCl}$ : relative to hydrochloric acid

Pepsin: relative to pepsin gastric enzyme 


\section{Simulation of the gastric digestion of proteins of meat bolus using a reaction-diffusion model}

Sicard Jason*, Mirade Pierre-Sylvain, Portanguen Stéphane, Clerjon Sylvie, Kondjoyan Alain

\section{INTRODUCTION}

Meat is a major source of dietary proteins that provide all the essential amino acids. The digestion rate of the proteins is known to be the main determinant of their assimilation in the diet, especially for sarcopenia-prone elderly people. ${ }^{1,2}$ Human digestion of foods is a multi-operation process in which mastication and gastric digestion have a major impact. The consumer's mastication capacity and the food's texture affect the average size and distribution of the particles in the bolus ${ }^{3-5}$, after which the stomach plays a major role in bolus particle breakdown, mixing and sieving, as well as in the acidoenzymatic destructuration of proteins. ${ }^{6}$ The stomach needs a low pH to activate pepsin, one of the main digestive enzymes, which cleave proteins into peptides and leads to amino acids such as phenylalanine, tryptophan and tyrosine. ${ }^{7}$ Most data on the gastric digestibility of meat has come through in vitro ${ }^{8-10}$ or in vivo studies on humans or animals. ${ }^{2,11}$ However, in vivo measurements only give a global indication of food digestibility while in vitro experiments, even when performed in sophisticated systems, are limited in mimicking the physiology of the human tract. ${ }^{8,12,13}$ Mathematical modeling of digestion offers an alternative approach that can provide information that is timeintensive and sometime impossible to obtain experimentally in vitro and in vivo. ${ }^{14-22}$

Myofibrillar proteins contribute $60 \%$ of meat protein content ${ }^{23}$. Pepsin digestibility of myofibrillar proteins has already been modeled in vitro by Kondjoyan et al. ${ }^{24}$ but their work was only a first approach and their model's results were not directly applicable to the digestion of proteins contained in the meat particles of the bolus. As myofibrils are hundred-micron-sized bodies, the diffusion of protons and pepsin and the food buffering capacity of the meat can be assumed to be of negligible effect. $\mathrm{pH}$ and pepsin concentration in the meat were thus assumed to be the same as in the surrounding fluid. In fact, this is not the case for the millimeter-sized particles contained in the bolus.

This paper reports simulation work predicting the effects of pepsin concentration, $\mathrm{pH}$ variations and meat particles size on the gastric digestion of proteins contained in bolus particles using a reactiondiffusion mathematical model. Kondjoyan et al. ${ }^{24}$ showed that cooking also has an impact on the kinetics and maximum digestibility of proteins, but that $\mathrm{pH}$ variation in the stomach had a much bigger effect (Kondjoyan et al. ${ }^{24}$, Fig. 4). Thus we focus on the impact of factors related to mastication and Affiliation: UR370 Qualité des Produits Animaux, Institut National de la Recherche Agronomique (INRA), 63122 Saint-GenèsChampanelle, France

*Corresponding author

e-mail addresses: jason.sicard@inra.fr (J.Sicard), pierre-sylvain.mirade@inra.fr (P-S.Mirade), stephane.portanguen@inra.fr (S. Portanguen), sylvie.clerjon@inra.fr (S.Clerjon), alain.kondjoyan@inra.fr (A. Kondjoyan) 
gastric digestion of raw meat and not on cooking. But the approach proposed remains fully transposable to cooked meat pieces.

\section{MATHEMATICAL MODELLING}

\subsection{MODEL MAIN ASSUMPTIONS}

The model principles are described in Fig. 1. Modelling begins at the entrance of the stomach. The solid bolus entering the stomach is assumed not to be a single coherent body but a collection of unlinked food particles which separate and rapidly get mixed with the gastric fluid due to gastric contractions. This assumption is supported by the fact that during wet sieving, that is used to determine particle sizes after mastication ${ }^{5}$, food particles separate indicating a low inter-particles bonding. The model is focused on the digestion of particles which size is greater than half a millimeter. The median size of the food particles in the bolus and their size distribution are taken from literature data. The particle size is assumed to remain the same during gastric digestion. Under physiological conditions, several thousand food particles in the micron-size range may also be present in the liquid phase of the bolus at the entrance of the stomach. The present simulations do not account for these particles, which represent a relatively low weight-by-mass proportion of the bolus. In the stomach, the food particles are subjected to the gastric fluid whose $\mathrm{pH}$ varies during digestion while Pepsin concentration is assumed to be constant.

Gastric digestion of millimeter size food particles is limited by the diffusion of pepsin inside the particles. In fact pepsin activity is also dependent on $\mathrm{pH}$. Thus particle digestion is also affected by the diffusion of the protons in the particle and by the buffering capacity of the food.

The mathematical approach followed in the paper is classically used in food engineering ${ }^{25,26}$. Mass transfers of pepsin and of protons are described by Fickian diffusions inside meat spherical particles; the initial pH of these particles being 5.5. The mathematical boundary condition chosen in the paper to describe the exchanges at the surface of these spherical particles is a Neumann-type equation. This equation presents the advantage to take indirectly into account the effect of particle movement in the stomach on the surface exchanges using a mass transfer coefficient, which value can be assessed using food engineering correlations and physiological measurements. Boundary conditions and diffusions equations lead to local pepsin and proton concentrations inside each food particle. A buffering term is added in the mass transfer of protons to take into account the effect of food composition on the local value of $\mathrm{pH}$ inside the particle. Local pepsin concentration and $\mathrm{pH}$ value are used to calculate a local digestibility index which varies with time. Time variation of the particle digestibility is calculated by averaging the local index in the entire volume of the particle. This value was compared with the 
maximum obtainable protein digestibility, which is achieved for a meat particle with zero buffering capacity left for an infinite time totally immersed in a gastric solution held constantly at $\mathrm{pH} 2$ and with a very high pepsin concentration. In such an optimal situation, we would have maximum digestion for all the proteins contained in the meat particle since the pepsin could reach all the cleavage sites available at a maximum active enzyme concentration.

The following sections detail the equations, the values of the model parameters and the calculations procedure used to simulate the digestion process. As we did not find reliable parameters to describe the buffering effect limiting the $\mathrm{pH}$ of the meat particle, a set of experiments was specially designed to quantify it. The reliability of the model assumptions is discussed during the presentation of the simulated results.

\subsection{EQUATIONS}

\subsubsection{DIFFUSION OF ACID AND PEPSIN}

Fick's second law used to describe the diffusion of the pepsin within the meat bolus particles was written as eq. 1.

$\frac{\partial \mathrm{E}}{\partial \mathrm{t}}=\mathrm{D}_{\mathrm{Pepsin}} \Delta \mathrm{E} \quad$ (eq. 1)

The Neumann boundary condition imposed on the partial differential equation 1 at the meat particlegastric fluid interface was eq. 2 .

$\Phi_{\text {Pepsin }}=k_{\text {Pepsin }}\left(E-E_{\text {Gastric }}\right)$

$k_{P e p s i n}$ was the mass transfer coefficient value used to describe the pepsin exchanges at the surface of the particle.

Pepsin activity is known to vary with $\mathrm{pH}$ depends on the type of pepsin and on the protein substrate. $\mathrm{pH}$-pepsin activity curves exist in model proteins like albumin or hemoglobin. ${ }^{27,28}$ The pepsin activity curve has an optimal pH above or below which it decreases. The decrease in activity of the enzyme between $\mathrm{pH} 2$ and $\mathrm{pH} 5$ is a lot less strong for human pepsin degrading albumin than for porcine pepsin degrading hemoglobin; the effect of substrate being determinant (the optimum $\mathrm{pH}$ for maximum pepsin activity being $1.5-2.5$ for hemoglobin vs 3 for albumin ${ }^{29}$ ). The function used in this study to describe pepsin activity was the function determined by Pletschke et al. ${ }^{28}$ for the reaction of hemoglobin with porcine and ostrich pepsins. The rationale justifying this choice is that this same function has already been validated for the substrate under study, i.e. beef myofibrillar proteins ${ }^{24}$, which form about $60 \%$ of total meat protein ${ }^{23}$. Furthermore, studies on human pepsin classically use porcine pepsin as a proxy standard due to its availability and similarity ${ }^{30}$. This function causes pepsin activity to drop rapidly as $\mathrm{pH}$ climbs from 2 , with a $50 \%$-plus activity reduction already at $\mathrm{pH} 3$. 
The local-point variations in $\mathrm{pH}$ inside these particles, which depends on the proton diffusion in the matrix and on the $\mathrm{pH}$ buffering capacity was described by the following system of equations 3 .

$$
\{\frac{\partial H_{F r e e}^{+}}{\partial t}=\underbrace{D_{H C l} \Delta H_{F r e e}^{+}}_{\mathrm{I}}-\underbrace{f\left(H_{F r e e}^{+}\right) D_{H C l} \Delta H_{F r e e}^{+}}_{\mathrm{II}}(\text { eq. } 3 b)
$$

In equation $3 b$, term I represents Fickian diffusion linked to the concentration gradient of $\mathrm{H}^{+}$ions whereas term II represents the decrease in this same concentration due to the composition of the meat media, where $f\left(H_{\text {Free }}^{+}\right)$is a function characterizing the buffering capacity of the meat. The $\mathrm{pH}$ buffering of meat is induced by the bonding of some hydrogen ions with proteins; the ions which remain unbounded being able to diffuse within the meat particles. The subscript "Free" has been added in the equations to represent these unbounded ions. When food comes into contact with gastric juice, there are other ion exchanges than $\mathrm{H}+$ that take place between the meat and its environment, but these exchanges are not considered in our model.

The literature has employed various approaches to account for $f\left(H_{\text {Free }}^{+}\right)$, ranging from introducing an apparent diffusivity value into Fick's law (equal to $D_{H C l}\left(1-f\left(H_{\text {Free }}^{+}\right)\right), f\left(H_{\text {Free }}^{+}\right)$being constant $)^{31}$ to constructing experimental relations to link buffering capacity to the composition and biochemical characteristics of different muscles. ${ }^{32}$ In this last study, buffering capacity was experimentally observed to vary almost linearly with $\mathrm{pH}$.

The Neumann boundary condition was eq. 4 .

$\Phi_{H_{\text {Free }}^{+}}=k_{\text {HCl }}\left(H_{\text {Free }}^{+}-H_{\text {Free Gastric }}^{+}\right) \quad$ (eq. 4)

where $\mathrm{k}_{\mathrm{HCl}}$ was the mass transfer coefficient of hydrochloric acid at the meat bolus particle-gastric fluid interface.

$\mathrm{k}_{\mathrm{HCl}}$ and $\mathrm{k}_{\text {Pepsin }}$ were estimated based on data found on the dynamic properties of gastric fluid and correlations derived from the literature, or identified based on our experimental data also used to determine the buffering capacity of meat. Under the hypothesis of spherical bolus particles fully immersed in a homogeneous gastric solution, there is no angular variation for concentrations.

From among the multitude of potentially workable correlations, we tested two classical correlations co-connecting the Sherwood number (Sh), Reynolds number (Re) and Schmidt number (Sc) in order to assess the impact of this choice on the calculations of the digestibility of proteins. 
The Sherwood, Reynolds and Schmidt dimensionless numbers can be related to the gastric flow conditions around meat bolus particles through eq. 5, 6 and 7 .

$$
\begin{aligned}
& S h=k /\left(D / L_{\text {car }}\right) \\
& R e=\left(\rho * \nu * L_{\text {car }}\right) / \mu \\
& S c=\mu /(\rho * D)
\end{aligned}
$$

The first correlation between those dimensionless numbers (eq. 8) corresponds to forced convection around a sphere ${ }^{33}$, whereas the second correlation (eq. 9) corresponds to a simplified mass transfer in a fluidized bed ${ }^{34}$, simplified because it neglects the Archimedes number. The rationale justifying this simplification is that there is little difference in density between gastric fluid and food bolus.

$$
\begin{aligned}
& S h=2.0+0.6 * R e^{1 / 2} * S c^{1 / 3} \\
& S h=0.14 * R e^{1 / 3} * S c^{1 / 3}
\end{aligned}
$$

The eq. 10 finally providing the mass transfer coefficients ensues from eq. 5.
$k=S h *\left(D / L_{c a r}\right)$
(eq. 10)

The characteristic length is the size of the meat particle.

The details on the gastric flow conditions chosen to calculate $k_{P e p s i n}$ and $k_{H C l}$ are given in section 3.2. Note that since ranges of Reynolds numbers in the stomach are directly available in the literature, eq. 6 has not been directly used in this paper.

\subsubsection{DIGESTION BY ACTIVE PEPSIN}

In order to predict digestibility, these equations were completed by the reaction model of pepsin digestibility of myofibrillar proteins from beef muscle developed by Kondjoyan et al. ${ }^{24}$ In this reaction model, the $\mathrm{pH}$-dependent activity of pepsin behaved like that of a diacid $\left(\mathrm{H}_{2} \mathrm{E}\right)$. Enzyme concentration was thus split between the active $\mathrm{pH}$-dependent component $E^{p H}$ and the total enzyme concentration $E$ based on the following relation (eq. 11):

$$
\frac{E^{p H}}{E}=\frac{H E^{-}}{H_{2} E+H E^{-}+E^{2-}}=\frac{1}{1+\frac{10^{-p H}}{K_{a 1}}+\frac{K_{a 2}}{10^{-p H}}}
$$

The fraction of active enzyme able to reach all the cleavage sites available on the protein, will be written in what follows as $E_{\max }^{* p H}$. It depends on prior thermal treatment of the meat, and is taken, here, as equal to that of the raw meat.

In practice, the value of $E_{\max }^{* p H}$ was computed from an optical density value that served to track the quantity of cleavage products, $\mathrm{P}$, amino acids or peptides, derived from the digestion of myofibrillar 
proteins. The linkage between constant $E_{\max }^{* p H}$ and the measurement was determined via a second constant $\delta_{\max }$ that accounted for calibration of the instrument (Kondjoyan et al. ${ }^{24}$; Table 1). Constant $E_{\text {max }}^{* p H}$ accounted for the amount of active enzyme that is $\mathrm{pH}$-dependent via eq. 11 .

The proportion of cleavage sites reached, leading to the formation of digestion-derived products, written $P$, in mass of protein digested ratioed to total mass of proteins in the meat, followed a firstorder reaction (eq. 12$)^{24}$, where $l_{f}$ is the kinetic constant of the reaction:

$P(t)+\frac{1}{l_{f}} \frac{d P(t)}{d t}=E_{\max }^{* p H} \frac{E^{p H}}{E^{p H}+L} \quad($ eq. 12)

The model developed ${ }^{24}$ concerned myofibrillar proteins in solution for which pepsin diffusion and acid diffusion were not rate-limiting, resulting in a constant value of $E_{\max }^{*} \frac{E^{p H}}{E^{p H}+L}$ in which the $\mathrm{pH}$ considered is the $\mathrm{pH}$ of the gastric juice.

The spatiotemporal variation in $\mathrm{pH}$ was added in the present model. This consequently made $E^{p H}$ into a variable that depended on the local enzyme and proton concentrations inside the meat. The equation solved at every point in the meat thus became (eq. 13):

$P(t)+\frac{1}{l_{f}} \frac{d P(t)}{d t}=E_{\max }^{* p H} \frac{E^{p H}(t)}{E^{p H}(t)+L}$

As time increases, the active enzyme concentration in the meat, $E^{p H}$, tends to be equal to the active enzyme concentration in the gastric fluid $E_{\text {Gastric }}^{p H_{\text {Gastric }}}$. The value of this active pepsin concentration is maximum for $p H_{\text {Gastric }}=2$. When enzyme concentration in the gastric fluid $E_{\text {Gastric }}$ is well above Las is the case for the gastric conditions studied here-and the gastric fluid is at optimum pH, i.e. $\mathrm{pH} 2$, the influence of the pseudo reaction rate constant $L$ becomes negligible.

Previous digestibility results were compared to the maximum value of the digestibility of meat proteins obtained in a previous paper using extracted myofibrils immersed in a pepsin solution at $\mathrm{pH} 2$. This maximum digestion situation is written $E_{\max }^{* p H=2}$ in what follows, and serves as reference in the rest of the paper. The relative digestibility term $\sigma$ was introduced to quantify the effect of pepsin and proton diffusion in the meat and of its buffering capacity on the mean digestibility of the particles contained in the bolus, compared to what would have happened for myofibrils immersed in the pepsin solution at $\mathrm{pH} 2$.

At a given point in time $t$, the mean value of $\sigma$ in volume $V$ of the meat particle equals (eq. 14). 
$\overline{\sigma(t)}=\frac{\frac{1}{V} \int P(t) d V}{E_{\max }^{* p H=2}}=\frac{\overline{P(t)}}{E_{\max }^{* p H=2}}$

In a first approximation, as the time-course change in particle size is not yet studied, volume $V$ is held constant.

In reality, the digestibility of the particle depends on residence time in the stomach. After ingestion of the bolus, the rate of gastric emptying starts with a lag phase during which there is very little emptying, followed by a linear phase of emptying. ${ }^{35-38}$ As this second phase is linear, the amount of particles exiting the stomach is constant over time. The mean digestibility of particles of a given size exiting the stomach, $\overline{\bar{\sigma}}$, can be calculated by eq. 15 .

$\overline{\bar{\sigma}}=\frac{\int_{t_{\text {lag }}}^{t_{\text {end }}} \overline{\sigma(t)} d t}{t_{\text {end }}-t_{\text {lag }}}$

$t_{\text {lag }}$ and $t_{\text {end }}$ being the end of the lag phase and the full emptying time respectively

\subsection{CALCULATIONS PROCEDURE}

The equations for the pure diffusion of pepsin and protons (with only the term I in eq. 3b considered in a first stage) were discretized by a finite difference method using the second-order Crank-Nicolson numerical scheme that has the advantage of being numerically stable and accurate. ${ }^{39,40}$ Details of the discretization procedure are not given here but can be found in Heat Transfer ${ }^{41}$. The model was implemented using MATLAB $^{\circledR} 2017$.

The function $f\left(H_{F r e e}^{+}\right)$was not determined directly but instead a stepwise approach was used during the Crank-Nicolson discretization (eq. $3 \mathrm{~b}$ term II). A parameter $K_{H}$ was introduced to decrease the local diffused proton concentration during a time step (eq. 16); this decreased concentration of proton being used for the calculus of diffusion during the next time step.

$p H_{t+\Delta t}-p H_{t}=K_{H}\left(-\log _{10}\left[H_{F r e e}^{+}\right]_{t+\Delta t}+\log _{10}\left[H_{F r e e}^{+}\right]_{t}\right)$

The local pepsin concentration and $\mathrm{pH}$ were used to calculate the local-point concentration of active pepsin (eq. 11) and digestion products (eq. 13).

The algorithm has been initialized at time $=0$, by determining the free protons concentration in the meat based on the mean $\mathrm{pH}$ measured on fresh meat samples, i.e. $\mathrm{pH}_{0}=5.5$ (eq. 17), through (eq. 18), whereas the initial concentrations of pepsin and digestion products $P$ were assumed as nil.

$\left[H_{\text {Free }}^{+}\right]_{0}=10^{-p H_{0}} \quad$ (eq. 18) 
The local-point kinetics of the $P(t)$ values thus obtained were used to determine $\overline{\sigma(t)}$ and $\overline{\bar{\sigma}}$ from equations (14) and (15) by considering a homogeneous initial composition of the meat-bolus particles.

As parameter $K_{H}$ was a priori unknown, it was determined from a special purpose-designed experiment and a minimization procedure described below in section 2 .

\section{EXPERIMENTAL PROCEDURE USED TO VALIDATE THE PH BUFFERING PART OF THE MATHEMATICAL MODEL}

The buffering capacity of the meat was determined using unidirectional measurement of $\mathrm{pH}$ in long meat cylinders mounted with the bottom in contact with a solution of $\mathrm{HCl}$, as done previously. ${ }^{31}$ These results were completed by $\mathrm{pH}$ measurements carried out at different time points on thin slices of beef meat immersed directly in the acid solution.

Meat was coming from two beef muscles (Longissimus dorsi and Infraspinatus) that had been taken from Charolaise-breed cattle then vacuum-sealed and aged for 10 days at $4^{\circ} \mathrm{C}$. Prior to the experiment, two $80 \mathrm{~mm}$-long $30 \mathrm{~mm}$-diameter cylinders were cut from in each muscle. These cylinders were each placed in a polyvinyl chloride (PVC) apparatus sat on top of a mesh to afford the flattest possible meat/acid contact surface (Fig. 2). $\mathrm{pH}$ of the hydrochloric acid solution was $2.0 \pm 0.1$. The solution was in contact with the bottom surface of the cylinder, and the apparatus was placed in an autoclave held at $37^{\circ} \mathrm{C}$ to mimic normal human body temperature. A sheet of aluminum foil was placed over the top of the apparatus to limit evaporation, and the solution was constantly shaken using a magnetic stirrer. The meat sample was mounted in such a way to be tightly squeezed by the edges of the plastic cylinder so as to limit capillary migration of acid along the sample edges.

Lebert \& Daudin ${ }^{31}$ had shown that $\mathrm{pH}$ change inside the cylinder was slow, so we were forced to experiment long contact times of $6 \mathrm{~h}, 18 \mathrm{~h}$ and $24 \mathrm{~h}$ in order to get measurable in-product $\mathrm{pH}$ change at a sufficient number of points over the height of the meat cylinder. These long trial times were not therefore physiologically representatives of gastric digestion, but were only used to validate the buffering part of the model.

At the end of the experiment, the meat cylinder was removed from the apparatus and frozen at $-20^{\circ} \mathrm{C}$ for 40 minutes. A $10 \times 10 \times 80-\mathrm{mm}$ parallelepiped was then cut from the center of the cylinder (to eliminate potential edge effects) and mounted in a cryostat and frozen to $-53^{\circ} \mathrm{C}$. A microtome (Microm HM 560, Thermo Scientific, France) was used to cut $500 \mu \mathrm{m}$-thick sections perpendicularly to the parallelepiped major axis. Then, each section was weighed, a mass of demineralized water 
corresponding to 9 times the sample mass was added to obtain a $1 / 10$ dilution, and the section-pluswater mixture was homogenized for 1 minute (Polytron PT-MR 2100, Kinematica, Switzerland). pH was measured using an InLab 427 puncture electrode (Mettler-Toledo, France) connected to a MA235 pH meter (Mettler-Toledo, France) plunged in the homogenate.

Complementary experiments on thin slices were carried out by plunging six $2 \mathrm{~mm}$-thick $30 \mathrm{~mm}$ diameter disks of meat sampled from the above muscles in a hydrochloric acid solution at $\mathrm{pH} 2.0 \pm 0.1$. Every 30 minutes, one of the disks was removed from the acid solution, weighed, and then measured for $\mathrm{pH}$ following the above protocol.

Fig. 3 reports the averages and \pm 2 standards deviation values obtained from these experiments.

\section{STRATEGY USED TO CALCULATE THE RELATIVE DIGESTION OF PROTEINS}

This paper set out to use the model described in part 1 to predict the effect of some human physiological factors on meat protein digestibility. However, uncertainty remains both on some of the model's intrinsic parameters and on the values of the factors describing the physiological phenomena under study.

Table 1 lists (1) the main factors needed to calculate the effects of physiological phenomena on protein digestibility and their potential range of variation, and (2) the intrinsic parameters introduced in the model, their most probable values, and their range of variation.

\subsection{REFERENCE VALUES OF THE FACTORS STUDIED IN THE PAPER}

The first physiological factor introduced in the model is the particle sizes, which have been measured on boluses coming from the mastication of food products. Age-related loss of masticatory performance is expected to increase the amount of bigger particles. ${ }^{50}$ The values of median particle size in the solid phase of ready-to-swallow boluses range from under $1 \mathrm{~mm}$ up to $6 \mathrm{~mm}$, with pork loin and frankfurters being near the upper bounds of that range. ${ }^{5,42}$ Given that these meat products share relatively similar mechanical properties to beef, we expected a similar median particle size range in the beef bolus considered in this study, with a range of variation between $3.5 \mathrm{~mm}$ and $5 \mathrm{~mm}$ depending on beef muscle type, maturation, and process.

The second physiological factor introduced is gastric $\mathrm{pH}$, for which physiological fasting value ranges from 1.3 to 2.1. ${ }^{51}$ However, Helicobacter pylori infection and atrophic gastritis are associated with decreased acid secretion in the stomach, and the prevalence of these conditions is higher in older subjects. ${ }^{52}$ We studied age-related impairment of acidification for fasting $\mathrm{pH}$ values up to $\mathrm{pH}$ 2.9. 
At the beginning of digestion, gastric $\mathrm{pH}$ is known to be much higher than its fasting value and to range from 4.5 to 5.8 depending on the meal's composition and the consumer's physiology. The time required to recover fasting $\mathrm{pH}$ level depends on food composition, food quantity, and food buffering capacity. ${ }^{53}$ In this study, the measurements of Malagelada et al. ${ }^{43}$ were chosen as a reference because the meal composition used in their paper is representative of that coming from an average American diet including 90 grams of beef meat.

The third physiological factor is pepsin concentration and activity in the gastric juice: pepsin secretion varies within the stomach, as the body of the stomach secretes significantly more pepsin than the antrum. For this study, we do not consider these stomach local variations in pepsin secretion, and instead we use the pepsin activity measured in the body of the stomach as the reference value. This value ranges from 180 to $780 \mathrm{U} / \mathrm{mg}$ protein (using hemoglobin as a reference substrate) between individuals. ${ }^{44}$ Pepsin output and total gastric fluid secretory volume output are parallel and proportional processes, so pepsin concentration in gastric juice can be regarded as constant. ${ }^{43,54}$

\subsection{SIMULATION APPROACH, REFERENCE VALUES AND UNCERTAINTY OF THE MODEL'S INTRINSIC PARAMETERS}

The mechanical movements of the stomach and residence time of food in it are also known to have an impact on food transformation. Kong \& Singh ${ }^{8}$ reviewed the state of the art in this field.

For each individual particle, as shown in section 1.2.1, the mass transfer at the gastric fluid-bolus particle interface depends on the Reynolds (Re), Sherwood (Sh) and Schmidt numbers (Sc), hence of the fluid velocity $(v)$, fluid dynamic viscosity $(\mu)$, fluid density $(\rho)$, of the particle size (under the Size = $L_{\text {car }}$ assumption) and of the diffusivities (D).

Fluid in the stomach has a non-Newtonian behavior. ${ }^{55,56}$ Abrahamsson et al. ${ }^{46}$ suggested that the in vivo fluid flow around $1 \mathrm{~cm}$-diameter tablets is laminar with a Reynolds number of an order of 0.01 to 30 , and in all cases orders of magnitude below those required for the existence of turbulence.

The flow velocity established by the propagation speed of antrum contraction waves is 2 to $3 \mathrm{~mm} . \mathrm{s}^{-}$ ${ }^{1}{ }^{47,48}$ The strongest fluid motion is around the lumen occlusion, with a velocity of up to $12 \mathrm{~mm} \cdot \mathrm{s}^{-1}$ in the narrowest region. ${ }^{20}$

The dynamic viscosity of the gastric juice in the stomach is in the range 0.01 to 2 Pa.s. ${ }^{45}$

The density of the gastric fluid is close to that of water..$^{45,46}$ 
The diffusivity values used for hydrochloric acid and for pepsin are the values corresponding to their mass diffusivity in water, as we work to the assumption that these chemical compounds diffuse essentially in the aqueous phase of the meat particles.

For the entirety of the solid food bolus, after ingestion, the rate of gastric emptying starts with a lag phase during which there is very little emptying, followed by a linear phase of emptying. The residence time of a piece of solid food in the stomach depends on composition of the meal, size of the piece, and physiological parameters. Residence time in the stomach, mechanical movements, and particles diameters are all inter-connected, since particle size is reduced during digestion. Gastric emptying is generally complete after 2 to 5 hours. ${ }^{35-38}$ In the reference situation used for this study, the lag phase lasts $1 \mathrm{~h}$ ( $\mathrm{t}_{\mathrm{lag}}$ ) and gastric emptying is complete after $4 \mathrm{~h}$ ( $\mathrm{t}_{\mathrm{end}}$ ) (see Fig. $4 \mathrm{a}$ and Malagelada et al. ${ }^{43}$ ). Particles with a size lower than 1 to $2 \mathrm{~mm}$ can pass through the pylorus and hence be emptied from the stomach into the duodenum. ${ }^{57}$

Particle digestion is calculated numerically and locally and then averaged to obtain mean particle gastric digestibility ratio over time (eq. 14) and mean particle gastric digestibility ratio over a gastric emptying period (eq. 15).

The result of the simulations depends on both the factors studied and their physiological variations and on the values of the model's intrinsic parameters which are known with a degree of uncertainty. We therefore used a hierarchical cluster analysis to confirm that the factors studied were effectively the major factors driving digestion and to have a study on the accuracy of the result linked to the uncertainties in knowledge of the parameter values.

The relative influences of parameters were evaluated using Statistica ${ }^{\circledR}$ (version 13.1). The weight matrix reflecting the covariance structure between the predictor and response variables was produced by partial least squares (PLS) regression. These weights are computed so that each of them maximizes the covariance between the digestibility (response) and the corresponding factor scores. Implementation of the NIPALS algorithm normalizes these weights.

Within the Statistica ${ }^{\circledR}$ PLS module, default settings were chosen. The dependent variable studied is the digestibility parameter $\overline{\bar{\sigma}}$ while the mass transfer correlation is a categorical predictor, and buffering, gastric pepsin activity, particle size, physiological gastric fluid dynamics parameters and acidification are continuous predictors.

\section{RESULTS AND DISCUSSION}

Hierarchical clustering confirmed that the two factors investigated in most depth in this paper, i.e. size of the bolus particles and variations in meat $\mathrm{pH}$, are the major factors dictating prediction of the gastric 
digestibility of meat. Pepsin content in the stomach does not appear to be a limiting factor. The indepth study of the result of the hierarchical clustering and the effect of parametric uncertainties on the digestibility values calculated by the model is presented in section 4.3 .

\subsection{DETERMINATION OF MEAT BUFFERING CAPACITY}

Modeling the $\mathrm{pH}$ buffering capacity of the meat bolus hinges on two parameters: the mass transfer coefficient $k$ which accounts for transfers between the fluid and the meat surface in our experimental device (Fig. 2), and the parameter describing the pH buffering capacity of the meat $K_{H}$ which accounts for the effect of the meat particle's chemical composition on its acidification. $K_{H}$ is determined primarily based on $\mathrm{pH}$ profile measurements in the meat cylinders whereas $k$ is determined on experiments conducted with meat slices completely submerged in the acid solution. The parameter pairs $\left\{k, K_{H}\right\}$ determined have to fit with all the experimental measurements in order to account for both buffering capacity within the product and surface exchange.

Experimentally-measured $\mathrm{pH}$ profiles inside thick cylinders show that $\mathrm{pH}$ change in the meat remains restricted to within a zone that is less than $10 \mathrm{~mm}$ thick, even for the longest experimental running times (Fig. 3a). Observations showed that for the acidification effect to become perceptible at depths of 5,8 and $10 \mathrm{~mm}$, the experiment had to be left to run for at least 6,18 and $24 \mathrm{~h}$, respectively (Fig. 3a). Furthermore, $\mathrm{pH}$ value in the first few tenths of a millimeter in from the surface showed relatively little variation during the first 18 hours of the experiment (Fig. 3a), whereas mean pH value in the 2 $\mathrm{mm}$-thick slice of meat decreased relatively steadily over the $3 \frac{1}{2} \mathrm{~h}$ experiment (Fig. 3b).

The $\left\{k, K_{H}\right\}$ parameter pairs have to be able to model the experimental results obtained both on cylinders and slices. The value space for $\left\{k, K_{H}\right\}$ is fairly wide when we only consider the $\mathrm{pH}$ profile measured on the cylinders at the $6 \mathrm{~h}$ trial time point, but it shrinks to an elliptical zone bracketed between the following intervals of variation: $3 \mathrm{E}-8 \mathrm{~m} \cdot \mathrm{s}^{-1} \leq k \leq 9 \mathrm{E}-9 \mathrm{~m} \cdot \mathrm{s}^{-1}$ and $0.014 \leq K_{H} \leq 0.031$, when also factoring in the profiles obtained after $18 \mathrm{~h}$ of trials. Adding the $\mathrm{pH}$ profiles measured at the $24 \mathrm{~h}$ trial time point narrows the value space down to just one parameter pair, i.e. $k=1.0^{ \pm 0.2} * 10^{-8} \mathrm{~m} . \mathrm{s}^{-}$ ${ }^{1}$ and $K_{H}=0.030^{ \pm 0.002}$. Note here that this parameter pair leads to calculated $\mathrm{pH}$ profiles on meat cylinders that are in very good agreement with the experimental results for distances-to-surface greater than $2 \mathrm{~mm}$ and experiment times of $6 \mathrm{~h}$ and $18 \mathrm{~h}$ (Fig. 3a). The calculation-measurement fit is not quite as good for local points very near the surface and for the $6 \mathrm{~h}$ experiment time point (Fig. 3a, experiment run for $6 \mathrm{~h}$ and measurements performed at less than $2 \mathrm{~mm}$ from the meat surface). Furthermore, the values predicted by the model do not match with the experimental measurement points for a $24 \mathrm{~h}$ trial. These calculation-to-measurement gaps are directly linked to the simplicity of the model used. This is because immersing the meat in a hydrochloric acid solution has the effect of 
not only causing protons to migrate to the meat but also causing meat ions to diffuse to the acid solution, which the model fails to predict and which explains the near-surface gaps observed in the pH profiles measured on the cylinder after $6 \mathrm{~h}$ of immersion. The big gaps observed on the cylinders at the $24 \mathrm{~h}$ experiment time point are directly linked to acid-driven degradation of the product, which again is not accounted for in the model.

Considering here all of the $\mathrm{pH}$ profiles obtained on the cylinders for contact periods ranging from $6 \mathrm{~h}$ to $24 \mathrm{~h}$ enabled us to narrow the value space down to just one pair of values for the $\left\{k, K_{H}\right\}$ parameter set, which accounts for both the effects of proton penetration into the meat and local-point $\mathrm{pH}$ variation in the product. Not considering acid-driven product degradation in the model did not affect the rest of the study, since the effects only materialize at experiment times upwards of $18 \mathrm{~h}$ whereas gastric degradation times are under $5 h .^{35-38}$

\subsection{SIMULATION OF THE EFFECT OF CHANGE IN GASTRIC PH OVER THE COURSE OF DIGESTION}

We used the previous diffusion-buffering mathematical model to predict the time-course change in $\mathrm{pH}$ of meat particles in the stomach. The size of the meat particles introduced in the calculations and assumed to remain constant during gastric digestion was either $2 \mathrm{~mm}$ or $4.25 \mathrm{~mm}$ : $2 \mathrm{~mm}$ reflects the size of particles able to exit the stomach via the pylorus ${ }^{57}$ and $4.25 \mathrm{~mm}$ reflects the median size of particle in the bolus after mastication ${ }^{5,42}$, which is assumed to remain the same when reaching the stomach. The $\mathrm{pH}$ of the meat particles reaching the stomach is also assumed to be equal to the $\mathrm{pH}$ of the fresh meat, i.e. $\mathrm{pH} 5.5$ on average.

Fig. 4a charts the time-course change in calculated mean pH inside $4.25 \mathrm{~mm}$-sized meat particles. When the model ignores meat buffering capacity and assumes a gastric $\mathrm{pH}$ at a constant 1.5 throughout digestion, meat pH drops to below 2.0 in less than 5 minutes, whereas it takes over 55 minutes as soon as the buffer effect is introduced (see Fig. 4a, curves 1 and 2). In reality, pH of the gastric fluid varies over the course of digestion, and is given here by the curve published by Malagelada et al. ${ }^{43}$ who observed a peak of gastric $\mathrm{pH}$ at approximately $\mathrm{pH}=4.7$ after meal ingestion followed by a fall to $\mathrm{pH}<3.0$ after 60 minutes. It takes more than $1 \frac{1}{2}$ hours to recover the baseline gastric $\mathrm{pH}$ level measured on the fasting subject used in the study (grey points, Fig. 4a). In this case, the pH drop in the meat particles is a lot slower and it takes over $90 \mathrm{~min}$ for meat $\mathrm{pH}$ to reach 3.0 and $180 \mathrm{~min}$ for meat pH to drop below 2.0 (see Fig. 4a, curve 3). In the case where in-stomach acidification is assumed to be more than $0.5 \mathrm{pH}$ units higher (translation of $+0.5 \mathrm{pH}$ of the curve of Malagelada) than in Malagelada et al. ${ }^{43}$ reference curve, meat $\mathrm{pH}$ remains higher than 2.0 even after 4 hours of digestion (see Fig. $4 \mathrm{a}$, curve 4). 
As pepsin activity is hugely dependent on $\mathrm{pH}$ change of the meat and its buffering capacity, these variations have a big impact on percentage of proteins digested.

In the case where gastric $\mathrm{pH}$ is at a constant 1.5 from start to finish throughout digestion, the times required to reach a relative digestion $\bar{\sigma}$ of $50 \%$ or of $75 \%$ compared to maximum myofibrillar digestibility, written $t_{\bar{\sigma}=50 \%}$ and $t_{\bar{\sigma}=75 \%}$, for the proteins contained in the $4.25 \mathrm{~mm}$-diameter meat particles are $1 \mathrm{~h}$ and over $1 \frac{1}{2} \mathrm{~h}$, respectively (Fig. $4 \mathrm{~b}$, curve 1 ). When $\mathrm{pH}$ of the gastrovascular cavity follows Malagelada et al. ${ }^{43}$ reference curve, it takes over $2 \mathrm{~h} 10 \mathrm{~min}$ and $2 \mathrm{~h} 50 \mathrm{~min}$, respectively, to achieve the same results (Fig. $4 \mathrm{~b}$, curve 2). These times were even longer when physiological factors caused the in-stomach pH values drift more than $0.5 \mathrm{pH}$ units from Malagelada et al. ${ }^{43}$ reference curve values, in which case $t_{\bar{\sigma}=50 \%}$ and $t_{\bar{\sigma}=75 \%}$ were $2 \mathrm{~h} 50 \mathrm{~min}$ and over $3 \mathrm{~h}$, respectively (Fig. $4 \mathrm{~b}$, curve 3 ).

In reality, the meat particles decrease in size over the course of digestion and only exits the stomach when they are less than $2.0 \mathrm{~mm}$ in diameter. In Fig. 4b, curve 4 simulates the effect of reducing particle diameter from $4.25 \mathrm{~mm}$ to $2.0 \mathrm{~mm}$ on protein digestion rate in the case where gastric $\mathrm{pH}$ follows the reference curve. The effect of this reduction of particle diameter decreases the $t_{\bar{\sigma}=50 \%}$ and $t_{\bar{\sigma}=75 \%}$ values by over 30 minutes when gastric $\mathrm{pH}$ is given by the reference curve (Fig. 4b, curves 2 and 4 ).

Thus a meat particle entering the stomach at a size of $4.25 \mathrm{~mm}$ and decreasing to a size of $2 \mathrm{~mm}$ would have a digestibility situated in-between the results obtained for $D=4.25 \mathrm{~mm}$ and $D=2 \mathrm{~mm}$ (Fig. $4 \mathrm{~b}$, curves 2 and 4$)$.

\subsection{EFFECT OF BIOLOGICAL VARIABILITY AND PARAMETER UNCERTAINTY ON PREDICTED MEAT DIGESTIBILITY}

The relative influence of the different factors and parameters given in Table 1 can be calculated using the PLS procedure described in section 3.2. Results in Fig. 5 show that bolus particle size and gastric $\mathrm{pH}$ deviation from Malagelada et al. ${ }^{43}$ reference profile are the most important biological factors, which impact protein digestibility. These two factors are equally important and can combine together. For example, there may be an age-related slowdown in acidification capacity in the stomach together with an age-related loss of masticatory efficiency that increases particle size in the food bolus. Peristaltic movements have far less influence that these factors, whereas gastric pepsin-related variation has only a minor effect in the concentration and activity range considered here. The uncertainty over the correlations and parameters to introduce in the model has a statistically significant effect on the results, but is still not high enough to undermine the conclusions on the effect of particle size and buffering capacity and the variation in gastric $\mathrm{pH}$ on meat protein digestibility.

\subsection{PROTEIN DIGESTIBILITY AT THE END OF GASTRIC DIGESTION}


In Table 1, the most probable conditions are flagged with superscript o whereas the favorable extremes are flagged with superscript + and the unfavorable extremes are flagged with superscript - . As the choice of correlation for the surface mass transfer coefficient is a categorical parameter that can take only two levels, we have opted to use the mean of the digestibilities obtained for the two correlations for the average case. Table 2 gives the change in digestibility as a function of particle size and $\mathrm{pH}$ gap to the physiological reference curve. Meat protein digestibility following particle residence time in the stomach is computed from eq. 15, accounting for the reference curve and potential gaps to physiological $\mathrm{pH}$. The cumulative impact of potentially viable variations on the physiological factors and the intrinsic model parameters can also serve to define the upper and lower bounds of this digestibility index, by considering the most favorable and least favorable extreme conditions (reported in \pm format in Table 2).

The results of the simulations in Table 2 tell us that the in-stomach relative digestion $\overline{\bar{\sigma}}$ of proteins contained in the meat particles decreases quasi-linearly as a function of both particle diameter and decline in stomach acidification compared to the reference curve. The relative loss of digestibility related to these two factors grows stronger as gastric conditions grow more limiting. Protein digestibility index $\overline{\bar{\sigma}}$ reaches $77 \%$ on exit from the stomach in the most favorable conditions, i.e. for $0.5 \mathrm{~mm}$-diameter particles following the reference $\mathrm{pH}$ curve, but falls to just $41 \%$ either when particle diameter increases up to $6 \mathrm{~mm}$ or when gastric $\mathrm{pH}$ deviates by one $\mathrm{pH}$ unit from Malagelada et al. ${ }^{43}$ reference curve (i.e. variation along the second column and the first row of Table 2, respectively). These two effects can compound to drive in-stomach protein digestibility down to practically zero.

The superscript values that account for the parameters connected with gastric mobility, via the mass transfer coefficient, have a substantially smaller effect than the parameters related to particle size or to variation in gastric $\mathrm{pH}$ value, and can even be considered negligible in the case of a very small initial particle size, where pepsin and proton diffusion will be fast regardless of particle movement in the stomach, but not in the case of bigger particle size, where a very low transfer coefficient can reduce protein digestibility $\overline{\bar{\sigma}}$ to practically zero. As indicated in the last row of Table 2, the calculated differences in digestibility values between a mobile particle and an immobile particle can be about as big as the digestibility value itself (i.e. $41 \%-34 \%$ in the last row of the first column of Table 2 , and $4 \%-$ $4 \%$ in the last row of the last column of Table 2 ).

Physiologically speaking, these factors all pull in the same direction. Advancing age tends to bring about a decline in masticatory capacity, hydrochloric acid secretion, and gastric motor function. Results of model output prove that these 3 effects are synergistic and can cause gastric protein digestibility to collapse from around $75 \%$ to $0 \%$. However, the very low digestibility thus obtained is underestimated 
due to the particles in the liquid phase of the food bolus that are not included in these estimates and yet contribute to dietary protein supply. The digestibility of these very small particles is not diffusionlimited and would therefore be higher, provided that the particles reside long enough in the stomach to make contact with the active pepsin.

In vivo experiments have proved that the utilization of meat for protein synthesis can be impaired by a decrease in the chewing efficiency of elderly subjects and that for elderly persons protein assimilation could be affected by meat cooking conditions ${ }^{2,58,59}$. On the contrary In vitro experiments performed in a TIM gastro-intestinal system seemed to conclude that age has little effect on the digestibility of meat protein $s^{60}$. However during these experiments ageing was only taken into account by a difference in the gastric acidification rate without considering the $\mathrm{pH}$ fasting value or the size of the bolus particles entering the stomach. The present modeling work bring complementary quantitative data which tend to prove that chewing and acidification problems can combine to decrease sharply the digestibility of proteins at the outlet of the stomach; this difference of digestibility being connected to the lack of assimilation of meat proteins by the elderly. Indeed, if the nature and the concentration of the peptides hydrolyzed at the entrance of the duodenum are determinant to limit muscle mass loss linked with sarcopenia as suggested by Boirie \& Guillet ${ }^{61}$, then the present model can be helpful to design new dietary strategies to decrease these detrimental effects in the elderly populations.

\section{CONCLUSION}

To the best of our knowledge, this work marks the first attempt to quantify the processes involved in gastric digestion of meat using a combined reaction-diffusion model. The reaction-diffusion model developed in this paper is able to provide quantitative data on the gastric digestion of meat proteins by pepsin, much of which would be hugely time-intensive if not impossible to obtain experimentally. The study shows that size of bolus particles and change in gastric $\mathrm{pH}$ have an overriding effect on the percentage of protein digested in the stomach and that the $\mathrm{pH}$ buffering capacity of the meat has to be accounted for to properly calculate the gastric digestibility of meat as soon as the bolus particle is a few millimeters large.

From a nutritional standpoint, the model developed here clearly shows the consumer age factor, as masticatory capacity and hydrochloric acid secretion tend to decrease and gastric motor function tends to get weaker with advancing age which could, in extreme cases, lead to a near-zero digestibility value. This age-related loss is further compounded by the fact that passage through the stomach is just one step-and one that occurs relatively quickly compared to the total time of end-to-end transit through the digestive system ${ }^{62}$ from preparation through to absorption in the small bowel. High in-stomach 
digestibility thus promotes a swift increase in amino acid concentration in the blood and consequently stimulates protein synthesis ${ }^{2}$, which could offer a nutritional strategy to counter sarcopenia. ${ }^{63}$

Even though the model provides undeniably valuable insights to help understand declining protein digestion in the stomach of older people, it still has room for improvement, especially in the way it accounts for the time-course change in particle size. Our model can be rapidly improved to take into account the progressive reduction of the particle size in the stomach connected to its digestion, while its possible breakdown into smaller particles would be more complex to describe mathematically. This would requires coupling with a disintegration kinetics model for meat particles, similarly to the one developed for carrot and ham ${ }^{64}$. Moreover this breakdown would have to be connected with particle movement which was only accounted for in the paper indirectly via the mass transfer coefficient at the meat particle-gastric fluid interface. Likewise, our approach considers the change in gastric $\mathrm{pH}$ as a model input taken from the literature, whereas in reality, hydrochloric acid and pepsin secretions occur concomitantly with successive filling and emptying of the stomach, and the variation in gastric $\mathrm{pH}$ could be predicted from these processes ${ }^{65}$ and from the volume of all the foods ingested in a meal and their respective buffering capacity. The gastric emptying rate, also taken from literature in this approach, could also be related to particles sizes ${ }^{66}$. This mass transfer-reaction model could thus be profitably complemented with models of fluid mechanics and buffering capacity in the stomach, which would pave the way to predicting the complete cycle of all these processes together.

Conflicts of interest: There are no conflicts of interest to declare.

Acknowledgments: This research received financial support from the INRA CEPIA department (AICDISCOM). The authors thank A. Truffier for her contribution to the implementation of the buffering model under MATLAB ${ }^{\circledast}$. The authors gratefully acknowledge the assistance of D. Remond and M-A. Peyron, who provided useful comments and suggestions on the interpretation of the simulated results. 
Table 1: List of (1) the main factors needed to calculate the effect of the physiological phenomena on protein digestibility and their potential range of variation, and (2) the intrinsic parameters introduced in the model, their most probable value and their range of uncertainty. In a list of values, the most probable value are indicated by the o superscript while the extremes most and least favorable digestion conditions used in the calculations are indicated by + and - superscripts, respectively.

\begin{tabular}{|c|c|c|c|c|c|}
\hline & Processes & \multicolumn{2}{|l|}{ Parameters } & Value spaces studied & Source \\
\hline \multirow{3}{*}{$\begin{array}{l}\text { (1) Main } \\
\text { factors } \\
\text { studied }\end{array}$} & Mastication & \multicolumn{2}{|c|}{ Particle size (diameter) } & $\{0.5,1,2,3.5,5,6\} \mathrm{mm}$ & 5,42 \\
\hline & $\begin{array}{l}\text { Gastric } \\
\text { acidification }\end{array}$ & \multicolumn{2}{|c|}{$\begin{array}{l}\text { Reference pH profile with } \\
\text { potential physiological gap }\end{array}$} & $\begin{array}{l}\text { Baseline } \mathrm{pH} \text { between } 1.3 \\
\text { and } 2.1-\text { healthy subjects } \\
\text { Baseline } \mathrm{pH} \text { up to } 2.9- \\
\text { sick patients }\end{array}$ & 43 \\
\hline & $\begin{array}{l}\text { Variation in } \\
\text { enzymatic } \\
\text { activity }\end{array}$ & \multicolumn{2}{|c|}{ Gastric pepsin activity } & $\begin{array}{c}\left\{180^{-}, 330,480^{\circ}, 630,780^{+}\right. \\
\} U / m g \text { of proteins (using } \\
\text { hemoglobin as substrate) }\end{array}$ & 44 \\
\hline \multirow{13}{*}{$\begin{array}{l}(2) \text { Intrinsic } \\
\text { model } \\
\text { parameters }\end{array}$} & $\begin{array}{l}\text { Variation in } \\
\mathrm{pH} \text { of meat } \\
\text { particles }\end{array}$ & \multicolumn{2}{|c|}{ Buffering capacity, $K_{H}$} & $\left\{0.014^{-}, 0.030^{\circ}, 0.031^{+}\right\}$ & $\begin{array}{l}\text { Experiment } \\
\text { (§2 and } \\
\S 4.1)\end{array}$ \\
\hline & \multirow{4}{*}{$\begin{array}{l}\text { In stomach } \\
\text { mobility of } \\
\text { meat } \\
\text { particles } \\
\text { accounted } \\
\text { for via the } \\
\text { value of the } \\
\text { convective } \\
\text { transfer } \\
\text { coefficient, } k\end{array}$} & \multicolumn{2}{|c|}{$\begin{array}{l}\text { Type of correlation used for } \\
\text { determining } k \text { and } k_{\text {Pepsin }}\end{array}$} & $\begin{array}{l}\text { Forced convection around } \\
\text { a solid sphere }{ }^{+} \text {or wall-to- } \\
\text { fluid mass transfer in } \\
\text { liquid-solid fluidized beds- }\end{array}$ & 33,34 \\
\hline & & \multirow{3}{*}{$\begin{array}{l}\text { Physiological } \\
\text { gastric fluid data } \\
\text { used in the } \\
\text { correlation }\end{array}$} & $\begin{array}{l}\text { Dynamic } \\
\text { viscosity, } \mu\end{array}$ & $\left\{0.01^{-}, 0.3^{\circ}, 2^{+}\right\}$Pa.s & 45 \\
\hline & & & $\begin{array}{l}\text { Reynolds } \\
\text { number, } \\
\text { Re }\end{array}$ & $\left\{0.1^{-}, 2^{\circ}, 30^{+}\right\}$ & 46 \\
\hline & & & Velocity, $v$ & $\left\{0.5^{-}, 2.5^{\circ}, 12^{+}\right\} \mathrm{mm} . \mathrm{s}^{-1}$ & $47,48,20$ \\
\hline & $\begin{array}{l}\text { Pepsin } \\
\text { diffusion }\end{array}$ & \multicolumn{2}{|l|}{ Diffusivity, $D_{\text {pepsin }}$} & $1.4 \mathrm{E}-10 m^{2} \cdot s^{-1}$ & 49 \\
\hline & $\begin{array}{l}\text { Acid } \\
\text { diffusion }\end{array}$ & \multicolumn{2}{|l|}{ Diffusivity, $\mathrm{DHCl}_{\mathrm{H}}$} & $3.3 \mathrm{E}-9 \mathrm{~m}^{2} \cdot \mathrm{s}^{-1}$ & 33 \\
\hline & & \multicolumn{2}{|c|}{$\begin{array}{l}\text { pseudo rate constant of } \\
\text { reaction } L\end{array}$} & $2.45 \pm 0.69$ & \\
\hline & $\begin{array}{l}\text { Pepsin- } \\
\text { driven }\end{array}$ & \multicolumn{2}{|c|}{$\begin{array}{l}\text { log10 of kinetic rate constant of } \\
\text { the absorption reaction on } \\
\text { cleavage sites } \mathrm{pKa}_{1}\end{array}$} & $1.6 \pm 0.2$ & \\
\hline & $\begin{array}{l}\text { protein } \\
\text { degradation }\end{array}$ & \multicolumn{2}{|c|}{$\begin{array}{l}\text { log10 of kinetic rate constant of } \\
\text { the desorption reaction on } \\
\text { cleavage sites } \mathrm{pKa}_{2}\end{array}$} & $2.5 \pm 0.3$ & 24 \\
\hline & & \multicolumn{2}{|c|}{$\begin{array}{l}\text { Kinetic rate constant of the } \\
\text { formation of products } I_{f}\end{array}$} & $0.025 \mathrm{~min}^{-1}$ & \\
\hline & Gastric & \multicolumn{2}{|l|}{$t_{\text {lag }}$} & $1 \mathrm{~h}$ & \\
\hline & $\begin{array}{l}\text { residence } \\
\text { time }\end{array}$ & \multicolumn{2}{|l|}{ tend } & $4 \mathrm{~h}$ & 43 \\
\hline
\end{tabular}


Table 2: Average value of $\overline{\bar{\sigma}}$ at the end of gastric digestion for increasing radius of the meat particles and $\mathrm{pH}$ deviations (a positive deviation is an upwards translation) from the reference curve of Malagelada \& al. ${ }^{43}$. Upper and lower bounds in the superscripts account for the most or conversely the least favorable digestion conditions (indicated by superscripts + and - in table 1), connected with pepsin activity, gastric dynamic behavior and meat buffering capacity. The column in bold gives the results obtained for the reference gastric $\mathrm{pH}$ evolution of Malagelada $\&$ al. ${ }^{43}$.

\begin{tabular}{|c|c|c|c|c|c|c|c|c|c|}
\hline & \multicolumn{6}{|c|}{ Difference in gastric $\mathrm{pH}$ to physiological reference } \\
\cline { 2 - 10 } & \multicolumn{4}{|c|}{ Healthy fasted $\mathrm{pH}$ range } & \multicolumn{5}{c|}{ Abnormal fasted $\mathrm{pH}$} \\
\hline Particle size $(\mathrm{mm})$ & -0.2 & $\mathbf{0}$ & 0.2 & 0.4 & 0.6 & 0.8 & 1 & 1.2 & 1.4 \\
\hline 0.5 & $75_{-4}^{+0}$ & $\mathbf{7 7}_{-5}^{+0}$ & $76_{-6}^{+0}$ & $72_{-7}^{+0}$ & $64_{-8}^{+0}$ & $53_{-7}^{+0}$ & $41_{-6}^{+1}$ & $31_{-6}^{+0}$ & $21_{-4}^{+1}$ \\
\hline 1 & $74_{-8}^{+0}$ & $\mathbf{7 5}_{-12}^{+1}$ & $74_{-16}^{+1}$ & $70_{-20}^{+1}$ & $61_{-20}^{+2}$ & $51_{-20}^{+1}$ & $39_{-16}^{+1}$ & $29_{-13}^{+1}$ & $20_{-10}^{+1}$ \\
\hline 2 & $70_{-21}^{+2}$ & $\mathbf{7 0}_{-29}^{+2}$ & $67_{-34}^{+3}$ & $62_{-37}^{+3}$ & $53_{-35}^{+4}$ & $43_{-31}^{+3}$ & $33_{-25}^{+3}$ & $24_{-19}^{+2}$ & $16_{-13}^{+2}$ \\
\hline 3.5 & $62_{-40}^{+4}$ & $\mathbf{5 9}_{-42}^{+5}$ & $54_{-42}^{+6}$ & $46_{-38}^{+7}$ & $38_{-33}^{+6}$ & $29_{-26}^{+6}$ & $21_{-19}^{+5}$ & $15_{-14}^{+4}$ & $10_{-9}^{+3}$ \\
\hline 5 & $50_{-39}^{+6}$ & $\mathbf{4 5}_{-37}^{+7}$ & $39_{-34}^{+8}$ & $32_{-29}^{+8}$ & $25_{-23}^{+7}$ & $18_{-17}^{+6}$ & $13_{-12}^{+5}$ & $9_{-9}^{+3}$ & $6_{-6}^{+2}$ \\
\hline 6 & $41_{-34}^{+8}$ & $\mathbf{3 6}_{-31}^{+8}$ & $30_{-27}^{+9}$ & $24_{-22}^{+8}$ & $19_{-18}^{+7}$ & $14_{-13}^{+5}$ & $10_{-10}^{+4}$ & $7_{-7}^{+3}$ & $4_{-4}^{+3}$ \\
\hline
\end{tabular}




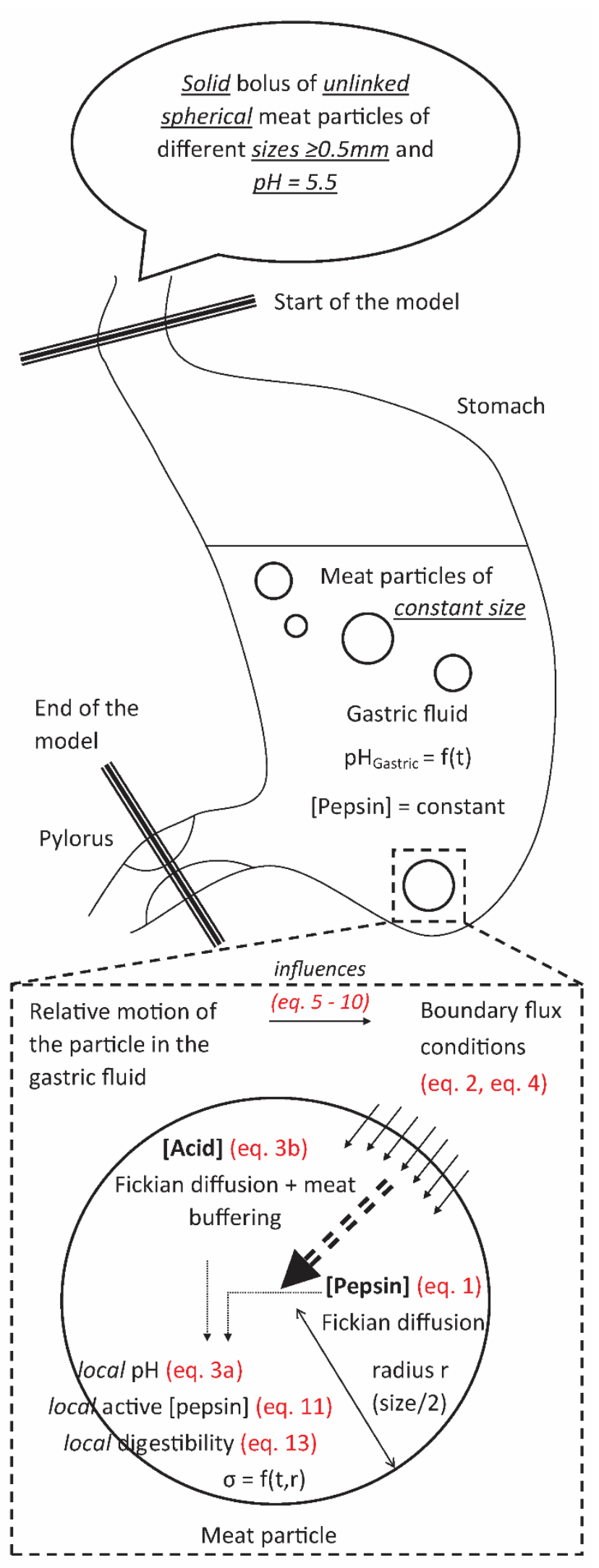

Figure 1: General description of the mathematical model and assumptions 


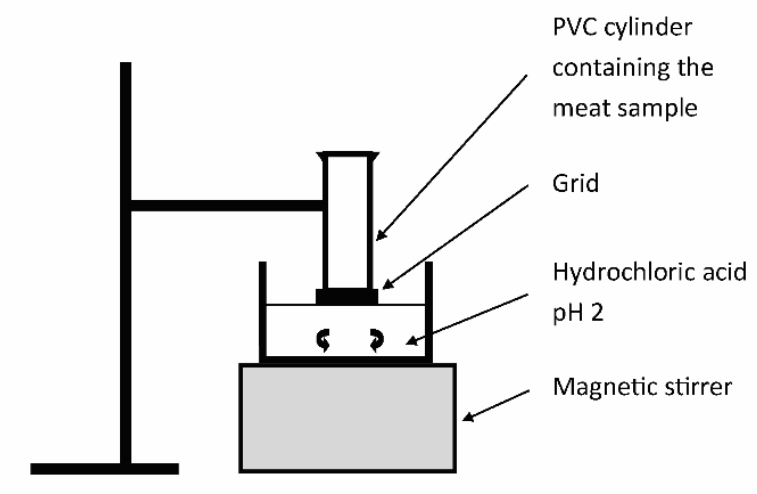

Figure 2: Experimental setup for meat acidification measurement 

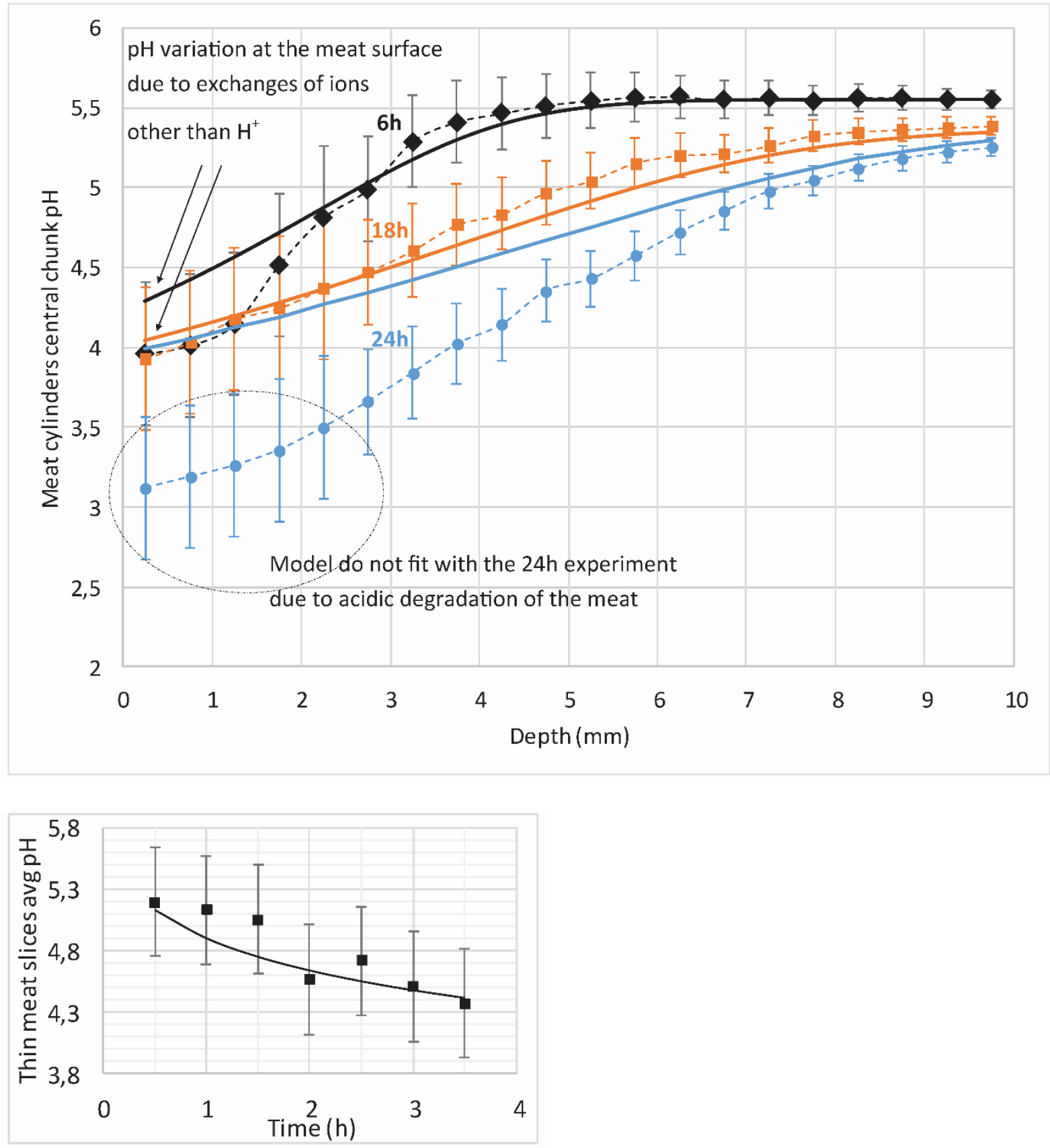

Figure 3: (a) pH profile measured in the first $\mathrm{cm}$ of the central portion of meat cylinders after different experimental times: $6 \mathrm{~h}$ (black, diamonds), $18 \mathrm{~h}$ (orange, squares) and $24 \mathrm{~h}$ (blue, circles), experimental mean points are linked by dashed lines. Solid lines are model predictions with $\mathrm{k}=1 \mathrm{E}-8 \mathrm{~m} \cdot \mathrm{s}^{-1}$ and $\mathrm{K}_{\mathrm{H}}=$ 0.030 for the following time periods: $6 \mathrm{~h}$ (black), $18 \mathrm{~h}$ (orange), $24 \mathrm{~h}$ (blue). (b) Time-course change in average $\mathrm{pH}$ in $2 \mathrm{~mm}$-thick meat slices immersed in acid solution (experiments: squares; simulation: solid line); (a, b) Experimental points represent mean values while errors bars represent $\pm 2 *$ standard deviations calculated on 3 repetitions. All unspecified model parameters are set at their reference value during these simulations, flagged with a superscript ${ }^{\circ}$ in Table 1. 

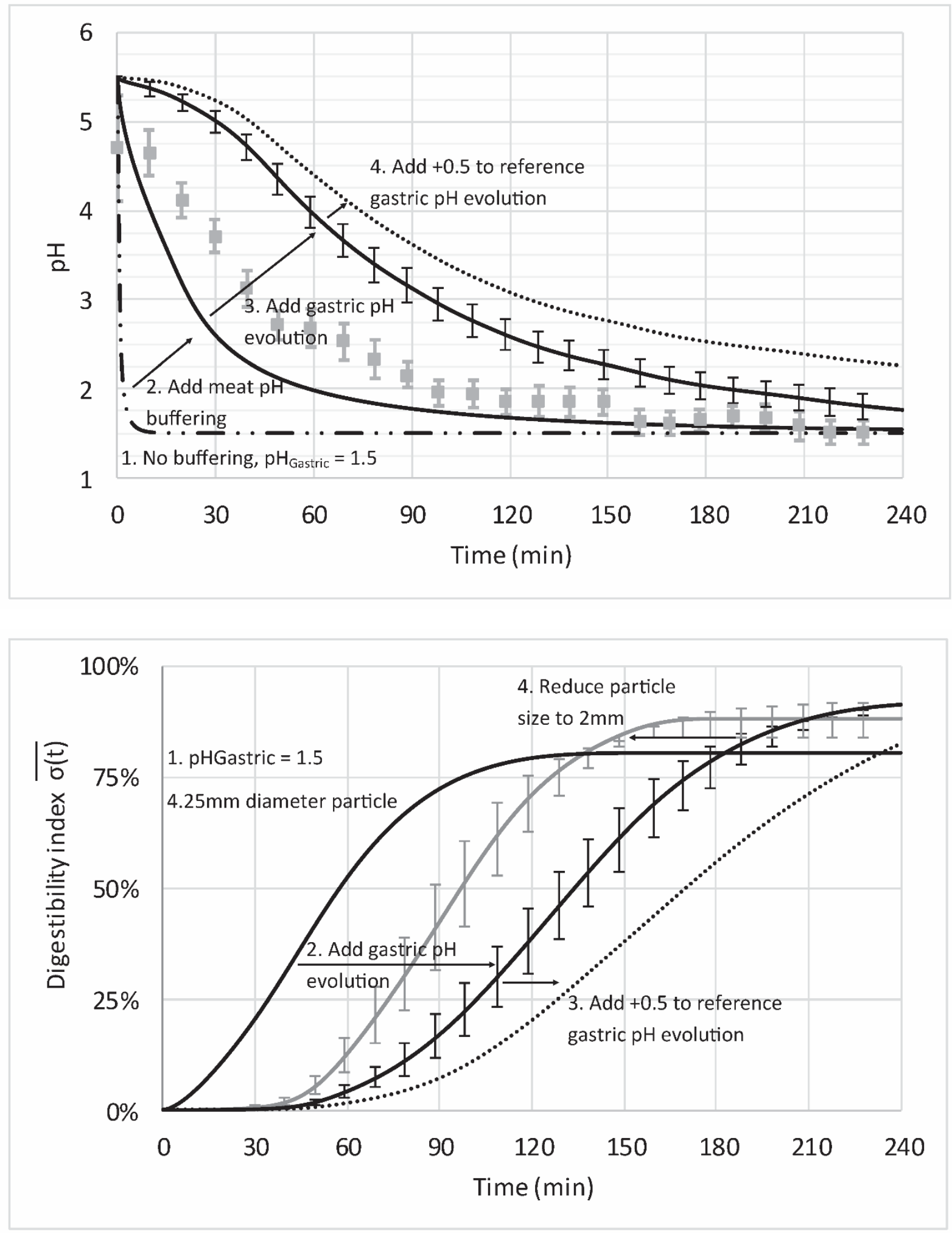

Figure 4(a): Average pH change of a $4.25 \mathrm{~mm}$-diameter meat particle. The grey square points with error bars show change in reference gastric $\mathrm{pH}$ measured by Malagelada $\&$ al. ${ }^{43}$ The 4 other curves are the calculated average $\mathrm{pH}$ of the particle. Unspecified model's parameters have been set at their reference value (superscript ${ }^{\circ}$ in Table 1). Simulations were performed: 1 (semi-dotted): with a constant gastric $\mathrm{pH}$ of 1.5 and without meat $\mathrm{pH}$ buffering, 2 (dashed): with a constant gastric $\mathrm{pH}$ of 1.5 and considering 
meat $\mathrm{pH}$ buffering, 3 (solid with error bars): with a reference gastric $\mathrm{pH}$ following the curve of Malagelada et al. ${ }^{43}$ (with errors bars showing the uncertainty propagation induced by the error bars on reference gastric change) and meat $\mathrm{pH}$ buffering, 4 (dotted): with addition of $+0.5 \mathrm{pH}$ units to the gastric $\mathrm{pH}$ curve of Malagelada et al. ${ }^{43}$ (upwards translation) and meat $\mathrm{pH}$ buffering.

Figure 4(b): Effect of particle size and gastric $\mathrm{pH}$. Meat buffering is always included in these simulations. All unspecified parameters of the model are set at their reference value (superscript ${ }^{\circ}$ in Table 1). Simulations of the digestibility index $\overline{\sigma(t)}$ were performed: 1 (black dashed): with a constant gastric $\mathrm{pH}$ of 1.5 and $4.25 \mathrm{~mm}$-diameter meat particle, 2 (black solid with error bars): with a reference gastric $\mathrm{pH}$ following the curve of Malagelada et al. ${ }^{43}$ and $4.25 \mathrm{~mm}$-diameter meat particle, 3 (black dotted): with addition of $+0.5 \mathrm{pH}$ units to the gastric $\mathrm{pH}$ curve of Malagelada et al. ${ }^{43}$ (upwards translation) and 4.25mm-diameter meat particle, 4 (grey solid with error bars): with a reference gastric $\mathrm{pH}$ following the curve of Malagelada et al. ${ }^{43}$ and $2 \mathrm{~mm}$-diameter meat particle. 


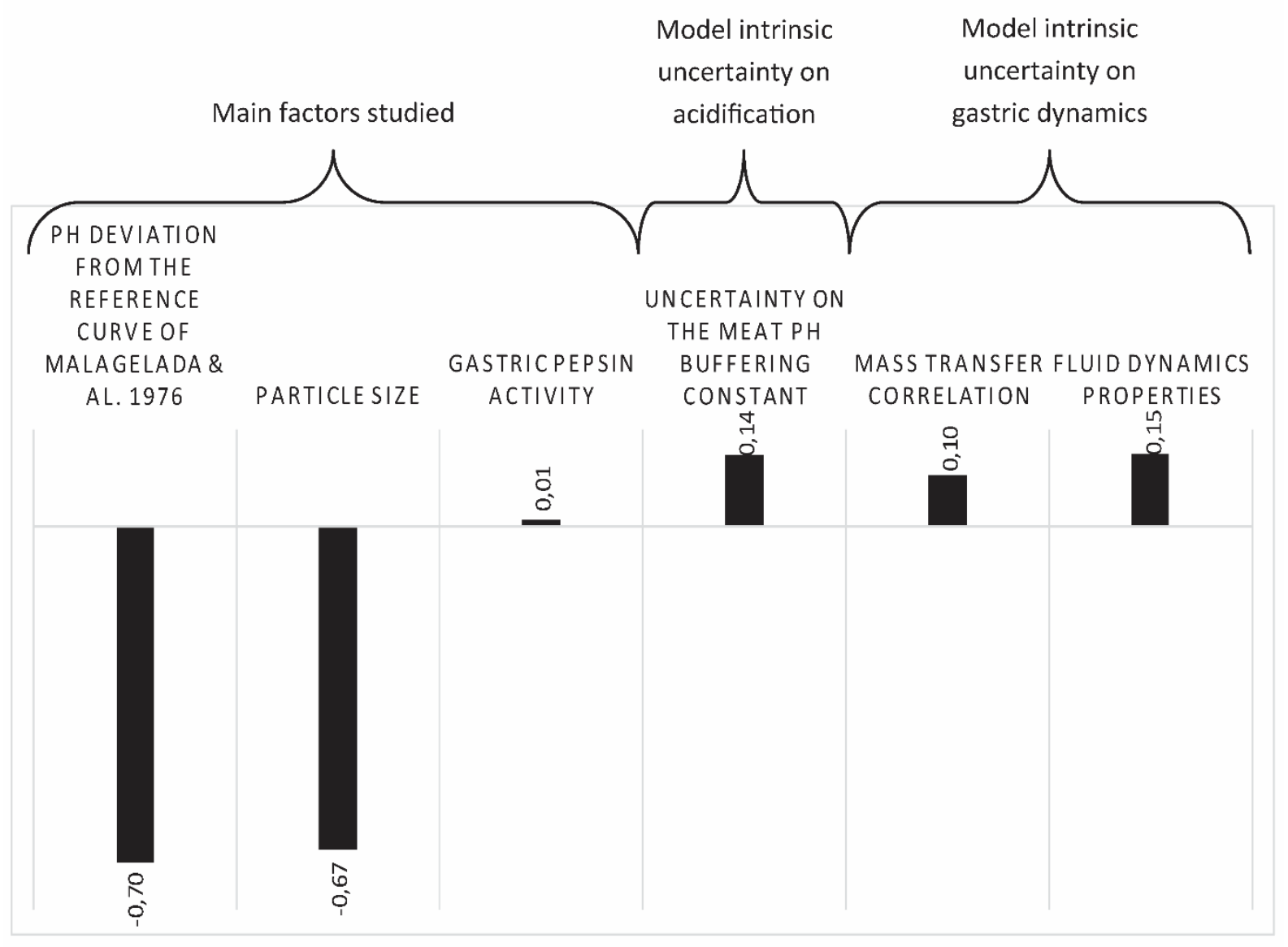

Figure 5: Impact of factors and uncertainties on meat protein digestibility. 


\section{REFERENCES}

1. M. Dangin, C. Guillet, C. Garcia-Rodenas, P. Gachon, C. Bouteloup-Demange, K. Reiffers-Magnani, J. Fauquant, $\mathrm{O}$. Ballevre and B. Beaufrere, The rate of protein digestion affects protein gain differently during aging in humans, J. Physiol., 2003, 549, 635-644.

2. D. Remond, M. Machebeuf, C. Yven, C. Buffiere, L. Mioche, L. Mosoni and P. P. Mirand, Postprandial wholebody protein metabolism after a meat meal is influenced by chewing efficiency in elderly subjects, $\mathrm{Am}$. J. Clin. Nutr., 2007, 85, 1286-1292.

3. K. R. Agrawal, P. W. Lucas, J. F. Prinz and I. C. Bruce, Mechanical properties of foods responsible for resisting food breakdown in the human mouth, Arch. Oral Biol., 1997, 42, 1-9.

4. C. Hoebler, M. F. Devaux, A. Karinthi, C. Belleville and J. L. Barry, Particle size of solid food after human mastication and in vitro simulation of oral breakdown, Int. J. Food Sci. Nutr., 2000, 51, 353-366.

5. M.-L. Jalabert-Malbos, A. Mishellany-Dutour, A. Woda and M.-A. Peyron, Particle size distribution in the food bolus after mastication of natural foods, Food Qual. Prefer., 2007, 18, 803-812.

6. G. M. Bornhorst, O. Gouseti, M. S. Wickham and S. Bakalis, Engineering Digestion: Multiscale Processes of Food Digestion, J. Food Sci., 2016, 81, R534-543.

7. B. M. Dunn, Overview of pepsin-like aspartic peptidases., Curr. Protoc. Protein Sci., 2001, 21.3, 1-6.

8. F. Kong and R. P. Singh, Disintegration of solid foods in human stomach, J. Food Sci., 2008, 73, R67-80.

9. M. L. Bax, L. Aubry, C. Ferreira, J. D. Daudin, P. Gatellier, D. Remond and V. Sante-Lhoutellier, Cooking temperature is a key determinant of in vitro meat protein digestion rate: investigation of underlying mechanisms, J. Agric. Food Chem., 2012, 60, 2569-2576.

10. L. Y. Yi, M. Van Boekel, S. Boeren and C. M. M. Lakemond, Protein identification and in vitro digestion of fractions from Tenebrio molitor, Eur. Food Res. Technol., 2016, 242, 1285-1297.

11. M. L. Bax, C. Buffiere, N. Hafnaoui, C. Gaudichon, I. Savary-Auzeloux, D. Dardevet, V. Sante-Lhoutellier and D. Remond, Effects of Meat Cooking, and of Ingested Amount, on Protein Digestion Speed and Entry of Residual Proteins into the Colon: A Study in Minipigs, PLoS One, 2013, 8, 1-7.

12. S. Bellmann, J. Lelieveld, T. Gorissen, M. Minekus and R. Havenaar, Development of an advanced in vitro model of the stomach and its evaluation versus human gastric physiology, Food Res. Int., 2016, 88, 191198.

13. I. Kobayashi, H. Kozu, Z. Wang, H. Isoda and S. Ichikawa, Development and Fundamental Characteristics of a Human Gastric Digestion Simulator for Analysis of Food Disintegration, Jpn. Agric. Res. Q., 2017, 51, 1725.

14. A. Pal, B. Abrahamsson, W. Schwizer, G. S. Hebbard and J. G. Brasseur, Application of a virtual stomach to evaluate gastric mixing and breakdown of solid food, Gastroenterology, 2003, 124, A673-A674.

15. A. Pal, K. Indireshkumar, W. Schwizer, B. Abrahamsson, M. Fried and J. G. Brasseur, Gastric flow and mixing studied using computer simulation, Proc. Biol. Sci., 2004, 271, 2587-2594.

16. T. E. Moxon, O. Gouseti and S. Bakalis, In silico modelling of mass transfer \& absorption in the human gut, J. Food Eng., 2016, 176, 110-120.

17. M. J. Ferrua, Z. J. Xue and R. P. Singh, On the kinematics and efficiency of advective mixing during gastric digestion - A numerical analysis, J. Biomech., 2014, 47, 3664-3673.

18. M. J. Ferrua and R. P. Singh, Computational modelling of gastric digestion: current challenges and future directions, Curr. Opin. Food Sci., 2015, 4, 116-123.

19. S. L. Hao, B. C. Wang and Y. Z. Wang, Density-dependent gastroretentive microparticles motion in human gastric emptying studied using computer simulation, Eur. J. Pharm. Sci., 2015, 70, 72-81.

20. H. Kozu, I. Kobayashi, M. Nakajima, K. Uemura, S. Sato and S. Ichikawa, Analysis of Flow Phenomena in Gastric Contents Induced by Human Gastric Peristalsis Using CFD, Food Biophys., 2010, 5, 330-336.

21. M. D. Sinnott, P. W. Cleary and S. M. Harrison, Peristaltic transport of a particulate suspension in the small intestine, Appl. Math. Model., 2017, 44, 143-159.

22. P. V. Trusov, N. V. Zaitseva and M. R. Kamaltdinov, A Multiphase Flow in the Antroduodenal Portion of the Gastrointestinal Tract: A Mathematical Model, Comput. Math. Method Med., 2016, DOI: $10.1155 / 2016 / 5164029$.

23. K. Maruyama, in Developments in Meat Science, ed. R. A. Lawrie, Elsevier Applied Science Publishers, London, vol. 3, 1985, pp. 25-50.

24. A. Kondjoyan, J. D. Daudin and V. Sante-Lhoutellier, Modelling of pepsin digestibility of myofibrillar proteins and of variations due to heating, Food Chem., 2015, 172, 265-271.

25. V. Gekas, Transport phenomena of foods and biological materials, CRC Press, Boca Raton, 1992.

26. D. R. Heldman and D. B. Lund, Handbook of Food Engineering, Marcel Dekker, Inc., New York, 1992. 
27. D. W. Piper and B. H. Fenton, pH stability and activity curves of pepsin with special reference to their clinical importance., Gut, 1965, 6, 506-508.

28. B. I. Pletschke, R. J. Naude and W. Oelofsen, Ostrich pepsin-I and pepsin-II - A kinetic and thermodynamic investigation, Int. J. Biochem. Cell. Biol., 1995, 27, 1293-1302.

29. J.-P. Raufman, in Encyclopedia of Gastroenterology, ed. L. Johnson, Academic Press, Cambridge, 2004, pp. 147-148.

30. G. L. Tritsch and C. R. Sachatello, Kinetic comparison of human, canine and porcine pepsins, Comp. Biochem. Physiol., 1971, 39, 715-718.

31. A. Lebert and J. D. Daudin, Modelling the distribution of $\mathrm{a}(\mathrm{w}), \mathrm{pH}$ and ions in marinated beef meat, Meat Sci., 2014, 97, 347-357.

32. M. V. Rao and N. F. S. Gault, The influence of fibre-type composition and associated biochemical characteristics on the acid buffering capacities of several beef muscles, Meat Sci., 1989, 26, 5-18.

33. E. L. Cussler, Diffusion Mass Transfer in Fluid Systems, University Press, Cambridge, 3 edn., 2009.

34. S. Schmidt, J. Buchs, C. Born and P. Biselli, A new correlation for the wall-to-fluid mass transfer in liquidsolid fluidized beds, Chem. Eng. Sci., 1999, 54, 829-839.

35. J. A. Siegel, J. L. Urbain, L. P. Adler, N. D. Charkes, A. H. Maurer, B. Krevsky, L. C. Knight, R. S. Fisher and L. S. Malmud, Biphasic nature of gastric-emptying, Gut, 1988, 29, 85-89.

36. K. Schulze, Imaging and modelling of digestion in the stomach and the duodenum, Neurogastroenterol. Motil., 2006, 18, 172-183.

37. M. Camilleri, J. R. Malagelada, M. L. Brown, G. Becker and A. R. Zinsmeister, Relation between antral motility and gastric-emptying of solids and liquids in humans, Am. J. Physiol., 1985, 249, G580-G585.

38. M. Camilleri, L. J. Colemont, S. F. Phillips, M. L. Brown, G. M. Thomforde, N. Chapman and A. R. Zinsmeister, Human gastric-emptying and colonic filling of solids characterized by a new method, Am. J. Physiol., 1989, 257, G284-G290.

39. A. Kondjoyan, O. Rouaud, M. S. McCann, M. Havet, A. Foster, M. Swain and J. D. Daudin, Modelling coupled heat-water transfers during a decontamination treatment of the surface of solid food products by a jet of hot air. I. Sensitivity analysis of the model and first validations of product surface temperature under constant air temperature conditions, J. Food Eng., 2006, 76, 53-62.

40. A. Kondjoyan, M. S. McCann, O. Rouaud, M. Havet, A. M. Foster, M. Swain and J. D. Daudin, Modelling coupled heat-water transfers during a decontamination treatment of the surface of solid food products by a jet of hot air-II. Validations of product surface temperature and water activity under fast transient air temperature conditions, J. Food Eng., 2006, 76, 63-69.

41. N. Özişik, Heat Transfer A Basic Approach, McGraw-Hill Book Company, New York, 1985.

42. A. Hennequin, M. A. Peyron, C. Ferreira, L. Aubry and V. Sante-Lhoutellier, Addition of fibers in Frankfurters modifies the ready-to-swallow food bolus properties and oral bioaccessibility of nutrients after in vitro mastication, 61st International Congress of Meat Science and Technology proceedings, Clermont-Ferrand, 2015.

43. J. R. Malagelada, G. F. Longstreth, W. H. J. Summerskill and V. L. W. Go, Measurement of gastric functions during digestion of ordinary solid meals in man, Gastroenterology, 1976, 70, 203-210.

44. J. DiPalma, C. L. Kirk, M. Hamosh, A. R. Colon, S. B. Benjamin and P. Hamosh, Lipase and Pepsin Activity in the Gastric Mucosa of Infants, Children, and Adults, Gastroenterology, 1991, 101, 116-121.

45. L. Marciani, P. A. Gowland, R. C. Spiller, P. Manoj, R. J. Moore, P. Young and A. J. Fillery-Travis, Effect of meal viscosity and nutrients on satiety, intragastric dilution, and emptying assessed by MRI, Am. J. Physiol.Gastroint. Liver Physiol., 2001, 280, G1227-G1233.

46. B. Abrahamsson, A. Pal, M. Sjoberg, M. Carlsson, E. Laurell and J. G. Brasseur, A novel in vitro and numerical analysis of shear-induced drug release from extended-release tablets in the fed stomach, Pharm. Res., 2005, 22, 1215-1226.

47. D. Bilecen, K. Scheffler, E. Seifritz, G. Bongartz and W. Steinbrich, Hydro-MRI for the visualization of gastric wall motility using RARE magnetic resonance imaging sequences, Abdom. Imaging, 2000, 25, 30-34.

48. M. A. Kwiatek, A. Steingoetter, A. Pal, D. Menne, J. G. Brasseur, G. S. Hebbard, P. Boesiger, M. Thumshim, M. Fried and W. Schwizer, Quantification of distal antral contractile motility in healthy human stomach with magnetic resonance imaging, J. Magn. Reson. Imaging, 2006, 24, 1101-1109.

49. B. E. Logan, in Environmental Transport Processes, John Wiley \& Sons, Hoboken, 2 edn., 2012, ch. 3, pp. 4950.

50. L. Mioche, P. Bourdiol, S. Monier, J. F. Martin and D. Cormier, Changes in jaw muscles activity with age: effects on food bolus properties, Physiol. Behav., 2004, 82, 621-627.

51. J. B. Dressman, Comparison of Canine and Human Gastrointestinal Physiology, Pharm. Res., 1986, 3, 123131. 
52. M. Feldman, B. Cryer, K. E. McArthur, B. A. Huet and E. Lee, Effects of aging and gastritis on gastric acid and pepsin secretion in humans: A prospective study, Gastroenterology, 1996, 110, 1043-1052.

53. L. Kalantzi, K. Goumas, V. Kalioras, B. Abrahamsson, J. B. Dressman and C. Reppas, Characterization of the human upper gastrointestinal contents under conditions simulating bioavailability/bioequivalence studies, Pharm. Res., 2006, 23, 165-176.

54. M. Vertzoni, J. Dressman, J. Butler, J. Hempenstall and C. Reppas, Simulation of fasting gastric conditions and its importance for the in vivo dissolution of lipophilic compounds, Eur. J. Pharm. Biopharm., 2005, 60, 413-417.

55. T. Takahashi and T. Sakata, Large particles increase viscosity and yield stress of pig cecal contents without changing basic viscoelastic properties, J. Nutr., 2002, 132, 1026-1030.

56. C. L. Dikeman and G. C. Fahey, Viscosity as related to dietary fiber: A review, Crit. Rev. Food Sci. Nutr., 2006, 46, 649-663.

57. A. Thomas, Gut motility, sphincters and reflex control, Anaesth. Intens. Care Med., 2006, 7, 57-58.

58. C. Buffiere, C. Gaudichon, N. Hafnaoui, C. Migne, V. Scislowsky, N. Khodorova, L. Mosoni, A. Blot, Y. Boirie, D. Dardevet, V. Sante-Lhoutellier and D. Remond, In the elderly, meat protein assimilation from rare meat is lower than that from meat that is well done, Am. J. Clin. Nutr., 2017, 106, 1257-1266.

59. M. Oberli, A. Marsset-Baglieri, G. Airinei, V. Sante-Lhoutellier, N. Khodorova, D. Remond, A. FoucaultSimonin, J. Piedcoq, D. Tome, G. Fromentin, R. Benamouzig and C. Gaudichon, High True Ileal Digestibility but Not Postprandial Utilization of Nitrogen from Bovine Meat Protein in Humans Is Moderately Decreased by High-Temperature, Long-Duration Cooking, J. Nutr., 2015, 145, 2221-2228.

60. S. Denis, T. Sayd, A. Georges, C. Chambon, S. Chalancon, V. Sante-Lhoutellier and S. Blanquet-Diot, Digestion of cooked meat proteins is slightly affected by age as assessed using the dynamic gastrointestinal TIM model and mass spectrometry, Food Funct., 2016, 7, 2682-2691.

61. Y. Boirie and C. Guillet, Fast digestive proteins and sarcopenia of aging, Curr. Opin. Clin. Nutr. Metab. Care, 2018, 21, 37-41.

62. J. L. Madsen and J. Graff, Effects of ageing on gastrointestinal motor function, Age Ageing, 2004, 33, 154159.

63. D. Remond, D. R. Shahar, D. Gille, P. Pinto, J. Kachal, M. A. Peyron, C. N. Dos Santos, B. Walther, A. Bordoni, D. Dupont, L. Tomas-Cobos and G. Vergeres, Understanding the gastrointestinal tract of the elderly to develop dietary solutions that prevent malnutrition, Oncotarget, 2015, 6, 13858-13898.

64. F. Kong and R. P. Singh, A model stomach system to investigate disintegration kinetics of solid foods during gastric digestion, J. Food Sci., 2008, 73, 202-210.

65. M. R. Kamaltdinov, P. V. Trusov and N. V. Zaitseva, Multi-component mixture flow in the stomach and duodenum allowing for functional disorders: results of numeric modelling for determining acidity, Russ. J. Biomech., 2017, 21, 205-223.

66. V. Ranawana, M. E. Clegg, A. Shafat and C. J. Henry, Postmastication digestion factors influence glycemic variability in humans, Nutr. Res., 2011, 31, 452-459. 